\title{
The Swiss zoologist Rudolf Burckhardt (1866-1908), pioneer in biohistory
}

\author{
By Pieter Smit
}

Carl Rudolf Burckhardt was born in Basle, 30 March 1866, son of Dr. Fritz Burckhardt, teacher and afterwards rector of the local gymnasium.

Rudolf was of delicate health, but endowed with intelligence and a very good memory. After his final examination he began his zoological studies at the Basle University in the spring of 1884. The zoologist and palaeontologist Ludwig Rütimeyer (1825-1895) appealed strongly to him, and after his teacher's death Burckhardt wrote an extremely readable biography (C. L. 1) *, showing deep admiration for his teacher and particularly the close relationship in ideas of the two men ${ }^{1}$. Like Rütimeyer, Burckhardt worked on zoomorphological and palaeontological problems, although Burckhardt paid more attention to the functional aspects; just like Rütimeyer, Burckhardt was only statisfied when his empirical findings could be fitted in logical systems, which often incorporated combinations of data from many related fields. Both shared a sceptical attitude towards Darwinism; Burckhardt even more so than his master. They were both interested in the classic authors and the history of zoology. Burckhardt even succeeded to introduce this history as an independent discipline in the university curriculum. Being both talented draughtsmen, their publications were skillfully illustrated.

In 1887 Burckhardt left Basle to continue his studies under His and Leuckart ${ }^{2}$ at Leipzig. Also to Wilhelm His Burckhardt devoted a scientific paper (C. L. 5), in which he analysed the former's significance for microscopic anatomy ${ }^{3}$; particularly his contributions regarding the histology and ontogenesis of the central nervous system had Burckhardt's special interest. In the autumn of 1888 Burckhardt continued his studies in Berlin under the

* C.L. points to the Chronological List of Burckhardt's biohistorical publications at the end of this paper. For a complete list of Burckhardt's publications, see G. Imhof, 1910: Prof. Dr. Rud.Burckhardt 1866-1906, in: Verhandl. der Naturforschenden Gesellschaft, Basel, 1910, p. 1-32; and Idem, 1910, in: Zoologische Annalen, vol.3, p. 156-176.

I wish to express my thanks to Professor Dr. H. Nüesch, Director of the Zoological Institute of the University of Basle, for sending me copies of those publications by Burckhardt which are not available in one of the Dutch public libraries. 
aegis of 0 .Hertwig ${ }^{4}$ and $\mathrm{W}$. Waldeyer ${ }^{5}$. It was here that he wrote his dissertation on histological researches on the spinal marrow of salamanders, with which he got his doctor's degree at Basle in $1889^{6}$. Hereafter he was appointed assistant of his former Berlin teacher Oscar Hertwig, in whose laboratory he carried out a series of studies on the central nervous system of the lower vertebrates (cf. Imhof's bibliography, items 4-9). At the same period more researches were carried out at the marine-biological laboratories at Rovigno (Istria) (1892) and Naples (1893).

In 1893 Burckhardt qualified as lecturer in zoology at Basle's University, to be appointed one year later as professor extra-ordinarius at the same university ${ }^{7}$ to lecture in palaeontology of vertebrates (a. o. Dipnoi), looking for the way in which this nervous system is integrated within the form and function on the whole organism. On account of these researches he opposed both the polygenetic interpretation of the Haeckel school, and the positivistic interpretation, which in his time became more prevalent. This search for morphological and functional interrelations is clearly expressed in two publications: Die Einheit des Sinnesorgansystems bei den Wirbeltieren ${ }^{8}$ (The Unity of the Sense Organ System in Vertebrates) and Das Zentralnervensystem der Selachier als Grundlage einer Phylogenie des Vertebratengehirns ${ }^{9}$ (The Central Nervous System of the Selachii as Basis for a Phylogeny of the Vertebrate's Brain).

Being appointed in 1899 as assistant at the Zoological Institute, he was in charge of the training courses of graduate students, in which function he contributed significantly to the collection of this institute. Then, in 1907, came his appointment as scientific director of the Zoological Station at Rovigno, which belonged to the Berlin Aquarium. Although he seemed happy in his new position, he decided, on the 14th of January 1908, to take his own life.

The striking characteristics of Burckhardt's empiric work are its thoroughness and careful attention to detail. He was working in many fields: marine zoology, histology, palaeontology, animal geography, pathology, teratology, veterinary science, and museology, but particularly in the field of comparative anatomy. In this latter field his attention was specially directed to the comparative anatomy of the central nervous system of lower vertebrates (Dipnoi, Selachii and bony fishes). To this theme were devoted 18 studies (cf. Imhof's bibliography); the problems encountered in brain research are clearly exposed in detail in Der Bauplan des Wirbeltiergehirns (1894) (The Structure of the Vertebrates' Brain). The all-encompassing work 
on these researches was to be: Das Zentralnervensystem der Selachier als Grundlage einer Phylogenie des Vertebratengehirns (1907) ${ }^{10}$ (The Central Nervous System of the Selachii as Basis for a Phylogeny of the Vertebrate's Brain). Here Burckhardt explained the close correlation between the brain structure and the animal's relative systematic position. Five volumes were planned, of which only the first was published, as a consequence of the author's premature death. In the introduction to this first part Burckhardt gave a full account of the whole work, from which we learn that the fifth and last volume was to contain a critical account of the history of the various methods employed in brain research. According to Imhof (Zool. Ann., p. 169) the whole work has a very original lay-out, is ambitious in style and independent in judgment. Burckhardt's researches involved frequent visits to the Zoological Station at Naples, where he was on friendly terms with its director Anton Dohrn.

Not only did Burckhardt try to interprete his data in a comparative anatomical, but also in a functional and phylogenetic way. According to him there should be a direct correlation between the complexity of the various systems of Sense Organs and the structure of the brain. In this respects he pointed with great emphasis to the enormous change which the system of tactile organs (of fishes) had to undergo during the the transition from life in water to life on land. This transition had to entail an enormous change in function which had to manifest itself also in the structure of the brain, indicating the wide gap existing between land- and water vertebrates (cf. note 7 ).

In this manner brain research and phylogeny are closely connected for Burckhardt, with phylogeny the dominant factor for the physiological processes. In his opinion phylogeny of the central nervous system was determined on the one hand by the (conservative) elements of the skull, on the other hand by the functional requirements of the senses. His personal opinion regarding this relationship between brain research and the doctrine of descent, clearly different from that of Haeckel, was something like a 'purified' phylogeny, averse to mechanistic as well as materialistic interpretations ${ }^{11}$. He obviously preferred a more vitalistic interpretation of these phenomena ${ }^{12}$.

His interest for the descendence question came also to the fore in his palaeontological studies, viz. his contributions to Das Gebiß der Sauropsiden (Imhof, item 17) (The Teeth of the Sauropsida).

Some of his treatises (cf. note 7) were devoted to ornithology, of which the 
most important is: Das Problem des antarktischen Schöpfungszentrums vom Standpunkt der Ornithologie (The Question of the Antarctic Creation Centre from the View of Ornithology) (Imhof, item 39). This study is a typical example of Burckhardt's endeavours to solve biological problems from a wider point of view and not to restrict himself to the positivistic interpretation. So he tried to solve the problem regarding the geographical distribution of the Ratitae (birds like the ostrich, emu, cassowary, etc.) around the southern hemisphere by way of comparative anatomy, thus demonstrating the common descent of these birds.

Worth mentioning is, furthermore, a number of studies on nestlings ${ }^{13}$. In one of these Burckhardt prepared his illustrations by the application of a new technique, consisting of a photograph, on which the colours were put in afterwards ${ }^{14}$. In another study Burckhardt applied radiography for his bird anatomy; he disclosed the results of these researches at the 5 th International Congress of Ornithologists at Paris in $1900^{15}$.

From the necrologies written by his pupil and friend, G. Imhof (see note on the first page of this paper) Burckhardt's personality emerges as a religiously feeling, great scientist, an affable person and a dedicated teacher. He was, moreover, an ardent art lover and was himself an excellent draughtsman. According to Imhof (p. 11-12) he possessed a sketchbook with beautiful drawings.

From 1898 to 1900 Burckhardt was president of the Naturforschende Gesellschaft (Association for Nature Research) at Basle and in 1898 he was elected as member of the Senckenbergische Naturforschende Gesellschaft (Senckenberg Association for Nature Research) and of the Deutsche Akademie der Naturforscher Leopoldina (German Academy for Nature Research Leopoldina).

Besides being a prominent zoologist, Burckhardt was deeply interested in the philosophical and historical background of his science.

He considered a thorough knowledge of the historical background to be important for every biologist, as he expected history to reveal the main lines along which his science had developed in the course of time. In this respect Burckhardt was a pioneer in a time when hardly any attention was paid to the historical background of science and biology was being split up in ever more disciplines, along with an expanding positivistic trend; more importance was attached to the discovery of new facts than to thoughtful consideration and a logical arrangement of the facts at hand. This point of 
view within biology at that time can also be considered as a reaction to the rigidity and inflexibility Haeckel had forced on biology ${ }^{16}$.

For Burckhardt the history of zoology was but a first stage of the history of biology in general, which itself could not be dissociated from outside developments in philosophy, theology, medical and inorganic natural sciences.

In his biographies Imhof enumerates four reasons which led Burckhardt to his historical researches.

Firstly his education in a culture-rich environment imbued with tradition. Besides, his most favourite teacher, Ludwig Rütimeyer, was very much concerned with the history of zoology. And Imhof further reveals that Burckhardt, during his stay in Berlin, was strongly influenced by the church historian Harnack ${ }^{17}$.

Secondly, from his studies on the lower vertebrates Burckhardt concluded that the current nomenclature of this taxon was abounding in errors, in systematic as well as in anatomical and physiological respect. Therefore he felt compelled to subject the entire generally accepted apparatus of conceptions to a critical revision, along with an investigation into the historical origins.

Thirdly, historical research should induce to repudiate the generally negative attitude of the professional biologist towards the philosophy of science, an attitude Burckhardt saw as a result of the growing influence of positivism in biology. To him the study of biology and that of its history are to each other as the two faces of Janus' head. To deny this would result in a 'depersonalizing effect' 18 .

As a fourth reason Imhof mentions the publication of a book, for which Burckhardt wrote a review (C. L.4). The author of this book, Jules Soury, attempted to link up the evolving conceptions regarding the central nervous system with biology in general, physiology, anatomy, pathology, psychology, and the history of civilization. This proposition must have carried Burckhardt's wholehearted approval.

Burckhardt's activities in the historical field began in 1893, with a series of courses on history of and criticism on Darwinism, a theme recurring in his successive lectures with ever more critical statements. Imhof's list of courses (p. 172-173) reveals that Burckhardt, in between his anatomic and palaeontologic courses, delivered several other series of historical lectures, a. o. on the history of zoology and biology in classical antiquity. Interest for these was apparently restricted to only a small circle. 
Until 1903 his publications in the field of history remained limited to a number of short biographies, of which those of Rütimeyer and His have been mentioned above. Alongside these appeared biographies of F.A.Göldi (C. L. 2) ${ }^{19}$ and Th.Bühler-Lindenmeyer (C. L. 3) ${ }^{20}$. Soury's book was reviewed in this same period.

Burckhardt's ultimate objective was to demonstrate, by means of his historical studies, the interrelationship between history on the one hand and classification of the biological sciences on the other.

His first important historical publication is devoted to this theme, titled: Zur Geschichte der biologischen Systematik (C. L. 6 and 7) (To the History of Biological Systematics). The problems dealt with played an important role in German-speaking countries, particularly after the publication of Haeckel's system of biology, which was based on the antithesis formfunction, i.e., morphology-physiology.

Burckhardt sharply attacked this bipartition: according to him physiology and anatomy are not opposed to each other; anatomy is the analytical method applied to the concrete parts of the living organism, while physiology is the analytical method to function, purpose and external environment.

Unlike Haeckel, he based his arrangement of the biological sciences on a double system, partly on the method used, partly on the object under study. Here he attempted to base his conceptions on historical ideas, beginning with Aristotle.

In the introduction of his Geschichte der Zoologie (C.L.22) (History of Zoology) Burckhardt returned once more to his classification of the biological sciences: «Geschichte und Systematik der Zoologie sind ... ohne einander undenkbar. Wir schicken daher die Grundzüge einer Systematik der Zoologie voraus, ehe wir ihre geschichtliche Entwicklung zu skizzieren suchen». (History and systematics of zoology are unthinkable apart from one another. We should therefore first examine the bases of zoologic systematics before trying to sketch their historical development).

Tschulok ${ }^{21}$, in his Das System der Biologie, p. 288-295, critically examined the construction of Burckhardt's system. On the one hand he could agree with a division of biology into sub-disciplines based on their methodology; on the other hand, however, he demonstrated that Burckhardt's two principles (method and object) did not lead to a logical interconnection of the two obtained systems.

Burckhardt's theoretic and philosophic-historic starting points are most clearly formulated in his Zoologie und Zoologiegeschichte (Zoology and 
History of Zoology) (C. L. 17). In addition should be mentioned the second of the Drei Reden (Three Lectures) entitled Biologie und Biologiegeschichte (Biology and History of Biology) (C. L. 19, 2).

According to Burckhardt the history of his field of science is usually not more than an appendix for the modern biologist, resulting from the unsettling process of specializations, as reflected in scientific pursuits and training where the analytic and empiric approach is considered the one and only all-important method, leaving hardly any chance to philosophical reflection on the given data. This approach could only result in the acceptance that every past discovery of some importance is supposed to be already incorporated in our body of scientific knowledge, reducing historical reflection to redundancy and loss of time.

In this light Burckhardt thought that the separation of science from its history must necessarily lead to an unbalanced knowledge and to the dissociation of science from its humanistic roots, involving all the inherent risks. He pointed out how biology originated in association with sociological, theological, philosophical etc. questions, resulting in many-still existing - close contacts with other sciences. Therefore biological problems cannot be solved by empirical science alone. Scientific knowledge by itself does not automatically include historical reflection; this can only result from a logical analysis of the underlying general conceptions.

For Burckhardt history meant more than chronology or the presentation of a historic background of the actual biological problems. He insisted on the necessity to disclose the roots of the ideas and to indicate their philosophical relationships and implications. This was his way to expose the main lines of development, a strinkingly modern attitude for the beginning of this century; he preferred to analyse the construction of ideas to just the sampling of new facts and formulations. His aim was to contribute to a further expansion of this science by understanding the historical development of the essentials of zoology. He was keenly aware of the dangers of a non-historic theoretic biology.

He furthermore considered a biological training essential for anyone who wants to study the history of biology, together with familiarity with the methods used in historical study and a personal examination of the sources handed down from the past. To this end Burckhardt saw the need to learn from the biographies of the great names in this field where the close contacts between teachers and pupils were so important.

Although Burckhardt was principally concerned with the field of the 
history of zoology, in his more general treatises he always pointed to the history of biology as a whole. As one of the direct results of his historical activities he expected a new incentive to those biological researches and methods, long since pushed to the background, thus giving fresh impetus to the present situation.

Of all periods of the history of biology, Burckhardt's first choice was Classical Antiquity, because it was then that biology was dominated in only a relatively small degree by theoretical conceptions, and the phenomenon of life was still regarded in its totality and plurality.

Love for this period dated from his early high-school years. Especially towards the end of his life he devoted himself to the question of the connection between science in his own time and that in Classical Antiquity, Being an eminent philologist he had read all the relevant literature. Again and again Burckhardt tried to demonstrate the great influence of the classical authors - particularly Aristotle - on the fundamental biological problems in the course of successive periods including his own. In his opinion one of the first obligations of science was to demonstrate the continuity and progress of the history of our civilisation; for him here lay the essential difference between the man of culture and the barbarian.

In one of his didactic studies Burckhardt tried to hold up a mirror to his contemporaries, with Greek science serving as reflector. The first of his Drei Reden (Three Lectures) (C. L. 19, 1) contains an imaginary conversation between himself, a collegue and an exfellow student. The colleague is solely interested and so engrossed in his own discipline that not time and/or attention can be spared for any historical reflection regarding the problems occupying his mind. However, in a dream Bruckhardt compels him to look at them in his way: together they travel to Cos, where they see Polybos and Hippocrates in action; they visit Athens where they meet Aristotle and Theophrastos, then Alexandria where they see Herophilos at work. With each visit Burckhardt demonstrates how familiarity with these Greeks can guide his colleague towards a real grasp and deeper comprehension of the problems in his research.

In a lecture for the Swiss Association of Gymnasium teachers Burckhardt made another attempt to arouse interest in Greek biology (C. L. 11).

He surmised that up until his own time Greek biological texts were for the greater part analyzed by theologians and philosophers, thus forcing the characteristics of Greek natural-scientific research into obscurity. The modern, empirically inclined scientist considers Greek natural science to be 
dominated by mysticism and superstition, rendering historic reflection trivial. This attitude certainly applied to biologists of Burckhardt's own time, as during the second half on the XIXth century the overall study of biology disintegrated into many 'logies'. And here Burckhardt saw the danger on the one hand of the disintegration of natural science in general and of biology in particular, and on the other hand the disconnection with the humanities.

It was in this respect that Burckhardt held up his Greek mirror to the modern biologist, demonstrating how Aristotle in particular started from the totality of the animal, fitting his data in the wider context of his overall knowledge of the vital phenomena of those animals familiar to him, carefully describing his observations, and assembling all data within a philosophic frame. Thus it became clear that Aristotle already proceeded from the three fundamental postulates: form (morphology), function (physiology) and development. These investigations of Aristotle into the generalities of zoology reveal practically all the basic conceptions of biology, albeit in still imperfect form. Hence Burckhardt concluded that biological science is obliged to turn to its original source. It is our duty to guard against the danger of the disintegration of natural science into an increasing number of new sub-sciences. Such an unbalanced development of the natural sciences with its inherent risks was seen by Burckhardt as a threat to our further spiritual development.

In an 'Open letter' (C. L. 14) Burckhardt sharply attacked Mauthner's "unhistorical" analysis of Aristotle's works ${ }^{22}$. In this analysis Mauthner denies Aristotle's importance for science and accuses Aristotle of having rather neglected empiricism in studying nature. Hence his influence on science was supposed to be ruinous and a particularly restraint for the development of biology. Burckhardt's criticism of Mauthner's book contains at the same time a defense of Aristotle's importance for biology in mediaeval, renaissance, as well as in Burckhardt's own time. He reproached Mauthner of having used erroneous and secondary sources.

In the same year of the 'Open Letter' (1904) Burckhardt published a most important contribution to the disposition of the first book of the Historia Animalium (C. L. 13). After a critical evaluation of the relevant literature he wrote a methodical analysis of this first book, concluding that originally the text should have started with chap. 6 and that chap. 1-15 should have been inserted between chap. 18 and 19. He correctly indicated that also in other works, come down to us, the transmitted sequence of text has later been 
proved to be inaccurate. In his analysis of Aristotle's text Burckhardt also made clear that Aristotle was already familiar with zootomy, not because of medical science but for its own sake, disclosing herewith a very early tendency that any investigation of organic nature should start from the object itself and not from some cosmological theory.

In 1904 Burckhardt published still another highly interesting treatise on the system of the animal kingdom, based on a text supposed to have been known before Aristotle and probably originating on the isle of Cos (C. L. 10). Starting point for this study was the work 'peri diaites' from the 'Corpus Hippocraticum', in which 52 animals are dealt with systematically, primarily based on their dietetical qualities. These 52 animals are dealt with in a sequence from the higher to the lower (domestic mammals, mammals in the wild, birds, fishes, lower animals). On further investigation this sequence appeared to be based not only on dietetical, but also on anatomical and physiological characteristics, with the striking feature that this was not a system of just animal taxa, but that within each taxon again certain arrangements could be distinguished. Essentially, the sequence of the animals studied was the same as we would have set up in accordance with our present state of knowledge. This was another proof for Burckhardt that the early Greeks took the living world around them as a field for research, and that the Cos animal system is the earliest one of the animal kingdom we know of, revealing the origin of the conception of the Chain of Being (Stufenleiter).

Burckhardt noted further that a comparison with the Historia Animalium shows that Aristotle essentially followed the same animal system, although he was able to fit 10 times more animals within it. Actually, Aristotle's system was the end of a period; after him the system deteriorated down the centuries.

On account of the Cos-, as well as the Aristotelian system, Burckhardt presumed that still an earlier-since lost-common source must have existed.

Posthumously two more of his studies on Greek biology appeared. In one of these Burckhardt tried to sketch the relationship which he thought to exist between Aristotle and Cuvier (C. L. 21) by demonstrating that Cuvier's Tableau Analytique and his later Règne animal were based on the foundation of Aristotelian zoology. He elucidated Cuvier's use of Aristotelian anatomy and physiology, noted however that Cuvier did pay too little attention to Aristotle's ideas on development, particularly to embryology and the conception of the Chain of Being. 
His very last study deals with a Hippocratic experiment (C. L. 20), in which he attempted to demonstrate that the Hippocratic School already performed experiments to solve a physico-chemical problem; in his opinion this could only have been done with a basic knowledge of experimentation with organic objects.

As a preliminary study to a general history of biology, Burckhardt stressed the need of a critical evaluation of the existing relevant literature and the availability of existing sources. Hence he critically evaluated three XIXth century works on the history of biology: J. V. Carus, 1872: Geschichte der Zoologie (History of zoology); J.Spix, 1811: Geschichte und Beurteilung aller Systeme in der Zoologie nach ihrer Entwicklungsfolge von Aristoteles bis auf die gegenwärtige Zeit (History and Judgement of all Systems in Zoology according to their Development from Aristotle up until the Present); and O.Schmidt, 1855: Die Entwicklung der vergleichenden Anatomie. Ein Beitrag zur Geschichte der Wissenschaften (Development of Comparative Anatomy. A Contribution to the History of Science) (C. L. 15 and 16).

In all three studies Burckhardt demonstrated the author's lack of knowledge of the works of Aristotle and other Greek authors. Of the works mentioned, that of Carus, is the only one which comprises the whole of zoology. Burckhardt's objections were directed to the emphasis put on developments in Germany, to a deficient knowledge about historical sources and to the frequent stresses on passages, which only carried some interest from a literary and/or cultural-historical aspect instead of from a direct zoological-historical aspect.

Spix' work has as subject the history of zoological classification. The first of its two volumes deals with the artificial systems, the second with the natural ones. The material of the first volume is arranged according to author's sequence; in the second it is arranged according to the different groups of animals, presenting suitable starting points for further research.

Finally, Schmidt's booklet contains the history of comparative anatomy. Burckhardt severely criticized the author for judging the earlier authors from contemporary standards and for being insufficiently accurate with the adopted conceptions. Even the term comparative anatomy has not been defined accurately; Burckhardt himself considered it extremely inadequate, because the conception anatomy would indicate an analytical method, while the conception comparative denotes a synthetical one. 
All through his life Burckhardt kept a watchful eye on the progress of his field of study within the secondary school's educational framework. In two lectures he brought forward his personal views. One, on the occasion of a yearly meeting of Swiss gymnasium teachers, was entitled: Mode und Methode in der Erforschung der organischen Natur (Mode and Method of Research in Organic Nature) (C. L. 18); a second text is to be found in his booklet Biologie und Humanismus (Biology and Humanism) (C. L. 19, 3).

Burckhardt took it for granted that education in biology in the gymnasium should closely link up with the classical authors and stress should be laid on the humanistic features of this science. He particularly wanted to discuss the attempts of modern biology to explain the complexity of organic nature by means of singular principles, implying a denial of its multiformity and leading to an inadmissable form of simplification by fitting the life phenomena within relative simple laws - comparable to those in physics and chemistry - where the characteristic biological processes are in danger of being overlooked. Here Burckhardt pointed to a number of phenomena occuring only in the living object and of which one of the most outstanding is that the parts of an organism are by the whole and not the other way round, like in the inanimate world. Furthermore Burckhardt wants biological terminology to be limited as much as possible and the current conceptions to be explained philologically as much as possible; all this to re-inforce the relationship between natural science and the humaniora. In this respect Burckhardt referred to the philological possibilities offered by biology as far as it is a descriptive science.

According to Burckhardt the educative value of biology in the curriculum is not dependent so much on the number of hours given than it is on the way of teaching. Biology's inherent logic should be explained as well as its methods and how its object can be characterized. To this purpose biology of classical antiquity offers the best approach, he said, as this was the only period in which biology could freely develop without having to cooperate in resolving problems of other sciences, like medical science, physics, or chemistry. Neither did theology impose its limits. With Aristotle's method the inherent oneness of biology can be demonstrated, as well as the dangers implied in specialization.

Burckhardt laid down the most complete summary of his studies and ideas in his booklet Geschichte der Zoologie (C. L. 22) (History of Zoology), published in the Sammlung Göschen (Leipzig, 1907). This booklet contains an abundance of new ideas and original opinions, effecting quite different 
conclusions from anything published in the field of the history of biology up to that time. Here too Burckhardt tried to demonstrate that the fundamental problems of zoology were outlined even in antiquity and that the greater part of the problems confronted in zoology in later times did not so much originate from this branch of science itself as being enforced upon it by other sciences, particularly by theology and medical science. Furthermore, this booklet offers, for the first time, a critic-historical review of the development of zoology in the second half of the XIXth century.

As a final addition may be mentioned that Burckhardt was one of the most eminent collaborators of the Zoologische Annalen (a journal for systematic, theoretical and historical zoology), founded by Max Braun (Koningsbergen) in 1904. His publications in this journal on Greek zoology were greatly appreciated, and not the least by philologists.

\section{Notes}

1. Carl Ludwig Rütimeyer was born at Biglen, Canton Berne, 26 February 1825 and died on 25 November 1895 at Basle.

He studied theology and then medicine at the university of Bern. In 1850 he received his Dr. Med. degree on a dissertation on the Swiss nummulitic terrains (N. B. the nummulities are fossil foraminiferous cephalopods, found in the Tertiary strata). The next three years were spent on a study tour through Europe, visiting the universities of Paris, London and Leiden. In 1855 he became ordinary professor of zoology and comparative anatomy at the university of Basle.

Rütimeyer made significant contributions to the natural history and evolutionary palaeontology of ungulate mammals. Particularly his studies on the meaning of dental characters for phylogenetic interpretations are of the highest importance (cf. Nelson, C. H., 1975: Dictionary of Scientific Biography, XII, p. 37-39).

His name remains closely connected with his famous study on the fauna of the Swiss lake dwellings: Die Fauna der Pfahlbauten der Schweiz (Denkschriften Allg. Schweiz. Ges. der gesammten Naturwiss. 19, No. 1, 1862). This study is often quoted by Darwin in his book on Variation under Domestication. Many of Rütimeyer's discoveries have been used by Karl von Zittel in his Lehrbuch der Palaeontologie.

Rütimeyer retired in 1893, but continued his studies until his death. His son Ludwig Leopold afterwards became professor of anthropology at Basle, where in 1901 he published his father's Gedichte von Ludwig Rütimeyer.

2. Karl Georg Friedrich Rudolf Leuckart (1822-1898) studied medicine at the university of Göttingen, obtained his Dr.Med. in 1845 and became lecturer in zoology at Göttingen (1847).

From 1850-1869 he held a professorship in the university of Giessen where he established his world fame in the field of parasitology. In 1869 he went to Leipzig, where he founded a new zoological institute (1880). 
Studies on marine invertebrates led him to the division of Cuvier's Radiata into Coelenterata and Echinodermata, and from this stems the division of the Metazoa in Coelenterata, Echinodermata, Annelida, Arthropoda, Mollusca and Vertebrata.

Fore more details, see: Rudolf Leuckart, Weg und Werk (Jena: Fischer).

3. Wilhelm His was born at Basle, 9 July 1831, and died at Leipzig, 1 May 1904. His research and teaching activities were in the fields of anatomy, histology, and embryology at the Universities of Basle (1847-1872) and Leipzig from 1872 onwards. During his Basler period he made - together with C. L. Rütimeyer - a study of the cranial from of the Swiss (Cranio helvetica, 1864).

He introduced many new techniques into the science of anatomy, and made many new discoveries, particularly in the field of histology. He also made use of photography (e.g., in his Atlas menschlicher Embryonen, 1880-1882).

Although he always tried to give a mechanistic explanation to biological processes, he has been one of the strongest opponents of Haeckel's interpretation of Darwin's theory. One of his most interesting books from the historical point of view is: Unsere Körperform und das physiologische Problem ihrer Entstehung. Briefe an einen befreundeten Naturforscher (1874). This book dedicated to his Leipzig colleague Carl Ludwig, cf. also: Querner H., 1972: Dictionary of Scientific Biography, VI, p.434-436.

4. Wilhelm August Oscar Hertwig (1849-1922) studied under Ernst Haeckel at Jena, and lived there from 1868 up to 1888. In 1878 he became extraordinary professor of anatomy and full professor in 1881. From 1888 up to 1921 he held the chair of cytology and embryology at the anatomico-biological institute at Berlin. On account of his special interest in the nature of the fertilization process he came to be an ardent promotor of the study of heredity on a cytological basis. He wrote a series of papers (together with his brother Richard) on the germ layer theory and the origin of the mesoderm.

For more details, see: Weissenberg, R., 1959: Oskar Hertwig 1849-1922. Leben und Werk eines deutschen Biologen (Leipzig).

5. Wilhelm von Waldeyer-Hartz (1836-1921) entered the university of Göttingen in 1856 to study natural science, continued his studies in Greifswald, and finished them under Karl Reichert, the Berlin embryologist and anatomist. There he also wrote his doctor's thesis on the structure and function of the clavicle.

Then Waldeyer went to teach physiology and histology at the university of Königsberg. In 1864 he moved to the university of Breslau where he taught physiology, histology and pathology. His work at that time was concentrated on the diagnosis of early cancer. From 1872 up to 1883 he held the chair of anatomy in the university of Strasbourg and from there he went to Berlin to succeed Reichert. Here he remained as director of the anatomy department for more than 33 years, during which period he acquired his reputation as a brilliant teacher.

For more details, see: Waldeyer-Hartz, W. von, 1921: Lebenserinnerungen, ed. 2 (Bonn). 6. Histologische Untersuchungen am Rückenmark der Tritonen (Basle, 1889).

7. According to Imhof, Verh. Natf. Ges. Basel, 1910, p. 6 he held his inaugural lecture on the descent of birds, one of his main fields of interest. (Cf. Imhof's bibliography, items 12, 17, 21).

8. Published in the Proceedings of the 5th International Zoological Congress, Berlin 1901, cf. Imhof's bibliography, item 37 . 
9. Published in the Nova Acta Leopoldina, vol. 73, no.2, cf. Imhof's bibliography, item 61.

10. Cf. note 9, and Imhof in Zool. Ann., p. 159 ff.

11. E. g., in his work «Das Zentralnervensystem der Selachier», cf. note 9 and Imhof, Zool. Ann., p.161-163. Cf. also Burckhardt's study on Zur Geschichte der zoologischen Systematik, p. 397-406 (C. L. 7).

12. In this respect he was greatly influenced by G.von Bunge (1844-1920). Von Bunge studied chemistry at the university of Dorpat (Tartu), received his Dr. Med. at Leipzig (1882) and came in 1885 to Basle, where he was appointed professor of physiological chemistry (1886). He specialized in nutritional physiology. Von Bunge was very active in the abstinence movement, considering alcohol consumption as one of the greatest evils of human society.

13. Studies on nestlings of birds are to be found in Imhof's bibliography, items 28, 29, 30 and 34.

14. Cf. his study on Der Nestling von Psophia crepitans und das Jugendkleid von Rhinochetus jubatus (Imhof, item 34).

15. Presumably published as: Le Poussin de Rhinochetus jubatus (Imhof, item 30).

16. Cf. Smit, P., 1967: Ernst Haeckel and his «Generelle Morphologie»: an evaluation (Janus 54: 236-252).

17. Adolf von Harnack (1851-1930) wrote a. o.: Medizinisches aus der Kirchengeschichte.

18. Imhof eites from a letter of Burckhardt to Max Braun, editor of the Zoologische Annalen: «Meiner Ansicht nach ist eine Befreiung der nachfolgenden Generation von der Langweiligkeit und entpersönlichenden Wirkung des gegenwärtigen Naturgeschichtsunterrichtes überhaupt nur denkbar, wenn wir die Naturforschung selbst humanisieren.»

19. Emil A. Göldi was a Swiss by birth (1859), pupil of Ernst Haeckel and later on director of the natural history museum at Pará (Brasil). He made many expeditions in the Amazone region and founded a zoological garden nearby his museum, in which he kept animals, belonging to the local fauna.

20. Theodor Bühler-Lindenmeyer (1859-1899), apothecary at Basle, died suddenly by a stroke of lightning. He was an amateur ornithologist and possessed a cabinet of eggs, nests and skeletons of birds and conchylia.

21. Tschulok, S., 1910: Das System der Biologie in Forschung und Lehre. Eine historischkritische Studie (Jena: Fischer).

22. Fritz Mauthner, 1849-1923, Austrian author and philosopher. Georg Morris Brandes (actually Cohen), 1842-1927, Danish author, critic and philosopher (cf. C.L. 14); lectured a. o. in Copenhagen and Berlin.

\section{Chronological list of Burckhardt's biohistorical publications}

1) Prof. Ludwig Rütimeyer (Allg. Schweizer Zeitung, 1895, Nr.281, 282, und 283, p.1-16).

2) E.A.Göldi und das Museum in Pará (Brasilien) (Die Schweiz, Jahrg. 1899, Heft 16, p. 577-579).

3) Theodor Bühler-Lindenmeyer. Geb. 18. August 1859. Gest. 29. Juni 1899. Nachruf (Verhandl. der Naturforschenden Gesellschaft, Basel, 12, 1900, p. 199-202).

4) Jules Soury. Le système nerveux central, structure et fonctions. Histoire critique des théories et des doctrines (Review in Zeitschr. für Psychol. und Physiol. der Sinnesorgane, vol. 27, 1901, p. 403-406). 
5) Zum siebenzigsten Geburtstage von Wilhelm His (Correspondenz-Blatt für Schweizer Ärzte, 1901, Nr. 13, p. 1-7).

6) Zur Geschichte der biologischen Systematik (Autoreferat) (Verhandl. der Naturforschenden Gesellschaft, Basel, 16, 1903, p. 1-3).

7) Zur Geschichte der biologischen Systematik (Verhandl. der Naturforschenden Gesellschaft, Basel, 16, 1903, p. 388-440).

8) Worte gesprochen bei Anla $\beta$ der Feier des Gedächtnisses an Friedrich Nietzsche in Weimar den 15. Oktober 1903, 3 p.

9) Extrait des Comptes rendus du $6^{\mathrm{e}}$ Congrès internationale de Zoologie, Session de Berne, 1904, 1 p.

10) Das koische Tiersystem, eine Vorstufe der zoologischen Systematik des Aristoteles (Verhandl. der Naturforschenden Gesellschaft, Basel, 15, 1904, p. 377-414).

11) Über antike Biologie. Vortrag, gehalten an der dreiundvierzigsten Jahresversammlung des Vereins schweizerischer Gymnasiallehrer, 4. und 5. Oktober 1903 in Baden (34. Jahresheft des Vereins Schweiz. Gymnasiallehrer, Aarau, 1904, p. 1-20).

12) Die Biologie der Griechen. Vortrag, gehalten in der wissenschaftlichen Sitzung am 9. Januar 1904 (Ber. der Senckenbergischen naturforschenden Gesellschaft in Frankfurt a/M., 1904, p.3-26). (The text of this address is almost literary the same as that under no. 19,1 ; therefore this publication is not reprinted in this collection).

13) Das erste Buch der aristotelischen Tiergeschichte (Zool. Annalen, 1, 1905, p.1-28 + 1 table).

14) Mauthner's Aristoteles. Offener Brief an Herrn Georg Brandes, 1904, 16 p. (Basel: Birkhäuser).

15) Zur Geschichte und Kritik der biologie-historischen Literatur. (I. J.V.Carus.) (Zool. Annalen, 1, 1904, p. 357-375).

16) Zur Geschichte und Kritik der biologie-historischen Literatur (II. Johannes Spix. III. Oscar Schmidt) (Zool. Annalen, 2, 1905, p. 31-46).

17) Zoologie und Zoologiegeschichte (Ztschr. wiss. Zoologie, 83, 1905, p. 376-383).

18) Mode und Methode in der Erforschung der organischen Natur. Vortrag gehalten an der fünfundvierzigsten Jahresversammlung des Vereins schweizerischer Gymnasiallehrer, 8. und 9. Oktober 1905 in Baden (36. Jahresheft des Vereins schweizerischer Gymnasiallehrer, Aarau, 1905, p. 46-59).

19) Biologie und Humanismus. Drei Reden, 1907, 88 p. (Jena: Diederichs). 1. Die Biologie der Griechen, p. 37-58; 3. Mode und Methode in Wissenschaft und Unterricht der Biologie, p. 59-87.

20) Ein hippokratisches Experiment (Festschrift zu Ehren von Prof.Kahlbaum, 1907, p. 73-80).

21) Aristoteles und Cuvier (Zool. Annalen, 3, 1907, p. 69-77).

22) G.Imhof: Rud.Burckhardt's Bedeutung für die vergleichende Anatomie und Biologiegeschichte (Zool. Annalen, 3, 1910, p.156-176) (with complete bibliography). 


\section{Zusammenfassung}

Darstellung der Biographie und der wichtigsten Publikationen des Schweizer Zoologen Rudolf Burckhardt (1866-1908). Er studierte in Basel, Leipzig und Berlin, arbeitete vorübergehend an den meeresbiologischen Stationen von Rovigno und Neapel und wirkte dann an der Universität seiner Heimatstadt Basel als Professor der Zoologie. Seine Forschungen betrafen vor allem das Zentralnervensystem der Wirbeltiere. Seine Bedeutung liegt darin, daß er die philosophischen und historischen Aspekte seiner Wissenschaft aufzeigte und sich intensiv mit den zoologischen und embryologischen Studien von Aristoteles und anderer antiker Schriftsteller beschäftigte. Er schrieb eine Reihe von Publikationen über die Geschichte der Biologie.

Prof. Dr. Pieter Smit

Biohistorisch Instituut

Nieuwe Gracht 187

3512 LK Utrecht 